\title{
First occurrences of the greater bonneted Eumops perotis (Molossidae) in the State of Paraná and synthesis of the known records for Brazil
}

\author{
Urubatan Moura Skerratt Suckow ${ }^{1,4}$, Gledson Vigiano Bianconi², \\ Lays Cherobim Parolin ${ }^{1}$ \& Isaac Passos Lima \\ ${ }^{1}$ Graduação em Ciências Biológicas, Pontifícia Universidade Católica do Paraná - PUCPR, \\ Rua Imaculada Conceição, 1155, CEP 80215-901, Curitiba, PR, Brasil, \\ e-mail: layscp@gmail.com \\ ${ }^{2}$ Instituto Neotropical de Pesquisa e Conservação, Rua Purus, 33, CEP 82520-75, \\ Curitiba,PR, Brasil, e-mail: bianconi@terra.com.br \\ ${ }^{3}$ Laboratório de Mastozoologia, Instituto de Biologia, Universidade Federal Rural do Rio de Janeiro - UFRRJ, \\ BR 465, Km 7, CEP 23890-000, Seropédica, RJ, Brasil, e-mail: isaac.passos@terra.com.br \\ ${ }^{4}$ Corresponding author: Urubatan Moura Skerratt Suckow, e-mail: urubatanmoura@ig.com.br
}

SUCKOW, U.M.S., BIANCONI, G.V., PAROLIN, L.C. \& LIMA, I.P. First occurrences of the greater bonneted Eumops perotis (Molossidae) in the State of Paraná and synthesis of the known records for Brazil. Biota Neotrop. 10(3): http://www.biotaneotropica.org.br/v10n3/en/abstract?short-communication+bn02310032010.

Abstract: Eumops perotis has just a few confirmed records in South America and an uneven distribution throughout the continent. In this paper, we show the first occurrence of this molossid in the State of Paraná, Southern Brazil and summarize all the known localities for the country.

Keywords: Chiroptera, Molossidae, distribution, new records, South America.

SUCKOW, U.M.S., BIANCONI, G.V., PAROLIN, L.C. \& LIMA, I.P. Primeiras ocorrências de Eumops perotis (Molossidae) no Estado do Paraná e sintese dos registros conhecidos para o Brasil. Biota Neotrop. 10(3): http://www.biotaneotropica.org.br/v10n3/pt/abstract?short-communication+bn02310032010.

Resumo: Eumops perotis apresenta poucos registros confirmados para a América do Sul, distribuídos de forma desigual por quase todos os países do continente. Nesta comunicação, nós relatamos a primeira ocorrência deste molossídeo no Estado do Paraná, Sul do Brasil e sumarizamos as demais localidades conhecidas para o país.

Palavras-chave: Chiroptera, Molossidae, distribuição, novos registros, América do Sul. 


\section{Introduction}

The genus Eumops was described by Miller (1906) in order to differentiate ten Chiropteran species that had been classified previously as Molossus Geoffroy, 1805 and Promops Gervais, 1856. The taxonomic record of the genus is complex and problematic; especially due disagreement regarding the patterns of craniodental measurements in the known forms (see Sanborn 1932, Eger 1977, Freeman 1981, Eger 2007, McDonough et al. 2008). Following the taxonomic review recommended by Simmons (2005), with the addition of the review of the South American forms summarized by Eger (2007) and contributions of Timm \& Genoways (2004) and Baker et al. (2009), the Eumops genus is currently represented by fourteen species: E. auripendulus (Shaw, 1800); E. bonariensis (Peters, 1874); E. dabbenei Thomas, 1914; E. delticus Thomas, 1914; E. glaucinus (Wagner, 1843); E. hansae Sanborn, 1932; E. nanus (Miller, 1900); E. patagonicus Thomas, 1924; E. perotis (Schinz, 1821); E. trumbulli (Thomas, 1901); E. maurus (Thomas, 1901); E. floridanus (Allen, 1932); E. underwoodi Goodwin, 1940; and E. wilsoni Baker, McDonough, Swier, Larsen, Carrera and Ammerman, 2009. Only the latter three species do not have confirmed records in Brazil (Tavares et al. 2008; Eger 2007; Sodré et al. 2008).

Eumops perotis is widely distributed across the American continent (Sanborn 1932, Eger 1977, Koopman 1982, Eger 2007). It has been recorded in the United States, Mexico, Cuba, Venezuela, Colombia, Bolivia, Equator, Peru, Paraguay, Argentina and Brazil (Sanborn 1932, de la Puente 1951, Marinkelle 1968, Best et al. 1996, Barquez et al. 1999, Simmons 2005, Eger 2007) (Figure 1). This species is the largest among its congeners, with forearm length ranging from 73 to $83 \mathrm{~mm}$ (Eger 1977, Best et al. 1996, Gregorin \& Taddei 2002). The ears are well-developed (from 36 to $47 \mathrm{~mm}$ ), extending beyond the nose (Sanborn 1932, Eger 1977), and the lip is without cutaneous folds (Gregorin \& Taddei 2002). Fur color ranges from light brown to dark gray, with a slightly paler abdomen and the wing membranes have a blackish tone (Best et al. 1996, Barquez et al. 1999). The cranium is robust and flat, and it has the largest measurements within the genus. The dental formula is $1 / 2,1 / 1$, $2 / 2,3 / 3 \times 2=30$, presenting a small first premolar which is usually displaced to the labial side of the maxillary tooth row; the first and the second molars are identical, with four comissures (Barquez et al. 1999). The third comissure of the third molar is one-quater the length of the second comissure (Eger 1977). In this paper we report the first occurrence of E. perotis in the State of Paraná, Southern Brazil, and summarize the records of the species in the country.

\section{Material and Methods}

We evaluated eight adult samples of the genus Eumops from three towns in the State of Paraná: Londrina (23 $19^{\prime} \mathrm{S}$ and $51^{\circ} 10^{\prime} \mathrm{W}$ ), one male caught in August, 2004; Maringá (23 24' S and 51 57' W), one female caught in October, 2007 and another one in July, 2009; and Três Barras do Paraná (25 $25^{\circ} \mathrm{S}$ and $\left.53^{\circ} 10^{\prime} \mathrm{W}\right)$, four females and two males caught in November, 2008. The latter seven specimens were sent to the "Laboratório Central do Estado" (Secretaria de Estado da Saúde do Paraná) and diagnosed as rabies-negative. Later, they were preserved in alcohol at the Museu de História Natural Capão da Imbuia, Brazil, with the numbers CTX 8679, CTX 8680, CTX 8681, CTX 8682, CTX 8683, CTX 8684, CTX 8685, CTX 8686, respectively. The specimens had their skulls removed (they were all very damaged with the basicranium broken) and linear measurements $(\mathrm{mm})$ of total length, tail length, ear length, forearm length, greatest length of skull, condyloincisive length, zygomatic breadth, postorbital constriction, maxillary toothrow length, breadth across molars and breadth across canines.

\section{Results and Discussion}

The morphological measurements we obtained are within the range described for E. perotis in South America (e.g. Eger 1977, Barquez et al. 1999) (Table 1). The records known for Brazil come from the States of Amazonas, Pará (Piccinini 1974), Maranhão, Piauí (Eger 1977), Mato Grosso (Escarlate-Tavares \& Pessoa 2005), Minas Gerais (Eger 1977, Falcão et al. 2003, Stutz et al. 2004), Rio de Janeiro (Schinz 1821 - type locality: "Campo dos Goytacazes, Villa São Salvador”; Eger 1977), São Paulo (Sodré \& Uieda 2001, Breviglieri et al. 2004, Uieda \& Chaves 2005), and Rio Grande do Sul (Pacheco \& Freitas 2003). Fossils of this species dated from the

Table 1. Measurements of the seven samples of E. perotis caught in the cities of Londrina (August, 2004), Maringa (October, 2007) and Três Barras do Paraná (November, 2008) in the State of Paraná, Brazil, compared to those ones taken by Eger (1977) and Barquez et al. (1999) for Argentina, Bolivia, Brazil (States of Goiás, Maranhão, Minas Gerais, Piauí and Rio de Janeiro), Equator, Paraguay, Peru and Venezuela. Abbreviations: TL - Total length; T - Tail length; E - Ear length; FA - Forearm length; GLS - Greatest length of skull; CIL Condyloincisive length; ZB - Zygomatic breadth; PC - Postorbital constriction; MTL - Maxillary toothrow length; BAM - Breadth across molars; BAC - Breadth across canines.

\begin{tabular}{|c|c|c|c|c|c|c|c|}
\hline \multirow[t]{3}{*}{$\begin{array}{l}\text { Measure } \\
(\mathrm{mm})\end{array}$} & \multicolumn{4}{|c|}{ State of Paraná, Brasil } & \multirow{2}{*}{\multicolumn{2}{|c|}{$\begin{array}{c}\text { Argentina, Bolivia, Brasil, Equator, } \\
\text { Paraguay, Peru and Venezuela } \\
\text { Eger (1977) }\end{array}$}} & \multirow{3}{*}{$\begin{array}{c}\text { Argentina } \\
\text { Barquez et al. (1999) } \\
\text { females and males } \\
\end{array}$} \\
\hline & \multirow{2}{*}{$\begin{array}{c}\text { Londrina } \\
1 \text { male } \\
\end{array}$} & \multirow{2}{*}{$\begin{array}{c}\text { Maringá } \\
\text { females }\end{array}$} & \multicolumn{2}{|c|}{ Três Barras } & & & \\
\hline & & & 4 females & 2 males & females & males & \\
\hline $\mathrm{TL}$ & - & $168-180(n=2)$ & $169-173$ & $173-175$ & - & - & $180.8 \pm 6.45(n=15)$ \\
\hline $\mathrm{T}$ & - & $60.1-70.1(n=2)$ & $62.7-66.4$ & $59.2-61.1$ & - & - & $62.3 \pm 4.02(\mathrm{n}=15)$ \\
\hline $\mathrm{E}$ & - & $44.7-44.9(n=2)$ & $39.9-42.1$ & $40.9-41.7$ & - & - & $45.9 \pm 4.66(n=15)$ \\
\hline FA & 79.1 & $73.8-80.9(n=2)$ & $77.6-81.3$ & $78.3-79.1$ & $78.56 \pm 0.35(n=33)$ & $80.22 \pm 0.49(n=21)$ & $78.3 \pm 2.33(n=17)$ \\
\hline GLS & - & $33.2(\mathrm{n}=1)$ & - & - & $32.52 \pm 0.11(\mathrm{n}=27)$ & $33.67 \pm 0.17(n=13)$ & $31.5 \pm 0.75(n=13)$ \\
\hline CIL & - & $32.2(\mathrm{n}=1)$ & - & - & $31.03 \pm 0.11(n=27)$ & $32.12 \pm 0.17(n=13)$ & $30.5 \pm 0.76(n=15)$ \\
\hline $\mathrm{ZB}$ & - & $18.9-19.6(n=2)$ & $18.1-18.7$ & $18.3-18.6$ & $18.41 \pm 0.08(n=29)$ & $19.04 \pm 0.13(n=15)$ & $19.0 \pm 0.45(\mathrm{n}=17)$ \\
\hline $\mathrm{PC}$ & - & $5.5-5.9(\mathrm{n}=2)$ & $5.4-5.8$ & $5.5-5.8$ & $5.35 \pm 0.04(\mathrm{n}=28)$ & $5.49 \pm 0.05(\mathrm{n}=15)$ & $5.5 \pm 0.18(n=18)$ \\
\hline MTL & - & $12.7-13.2(\mathrm{n}=2)$ & - & - & $12.18 \pm 0.05(n=29)$ & $13.14 \pm 0.11(n=16)$ & $12.8 \pm 0.27(\mathrm{n}=18)$ \\
\hline BAM & - & $12.5-13.4(\mathrm{n}=2)$ & $12.9-13.2$ & $12.9-13.3$ & - & - & $13.2 \pm 0.26(\mathrm{n}=18)$ \\
\hline $\mathrm{BAC}$ & - & $8.1-8.6(n=2)$ & $7.7-8.1$ & $7.8-8.4$ & - & - & $8.6 \pm 0.19(n=18)$ \\
\hline
\end{tabular}




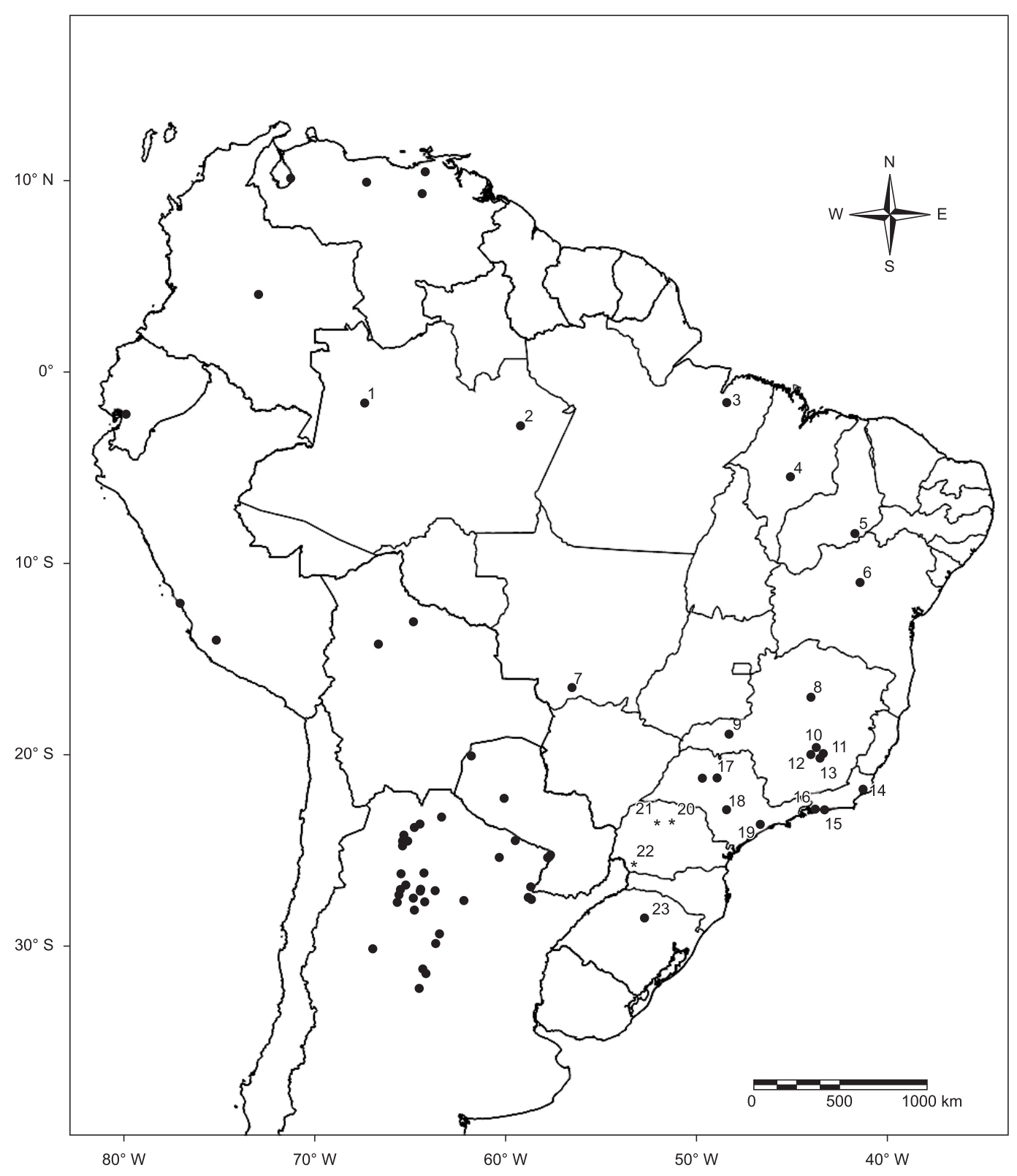

Figure 1. Distribution of the E. perotis in South America (Venezuela, Colombia, Bolivia, Equator, Peru, Paraguay and Argentina), with summary records confirmed for Brazil. 1) Paranã do Manhana, Amazonas (approach point 1 ${ }^{\circ} 50^{\prime} \mathrm{S}$ and 67 $\mathrm{W}$ ) (Eger 1977 corrected); 2) "Rodovia Estadual AM-010" (Manaus

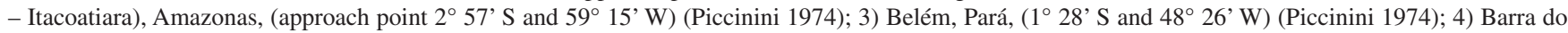

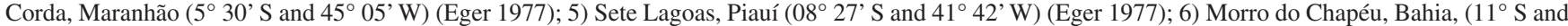
$41^{\circ} 25^{\prime}$ W) (Czaplewski \& Cartelle 1998); 7) Barão de Melgaço, Mato Grosso (16³ 30'S and 6 30’ W) (Escarlate-Tavares \& Pessoa 2005); 8) Rio Velhas, Minas

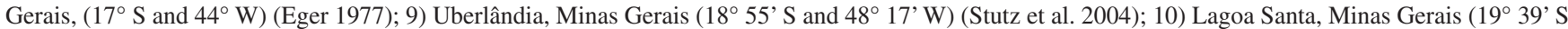

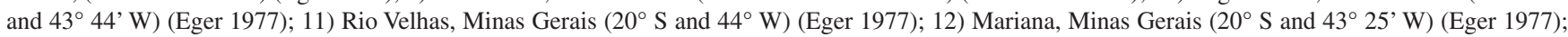
13) Serra do Caraça, Minas Gerais (20 05' S and $43^{\circ} 29^{\prime}$ W) (Falcão et al. 2003); 14) Campos dos Goitacazes, Rio de Janeiro ( $21^{\circ} 49^{\prime} \mathrm{S}$ and $41^{\circ} 16^{\prime} \mathrm{W}$ ) (type

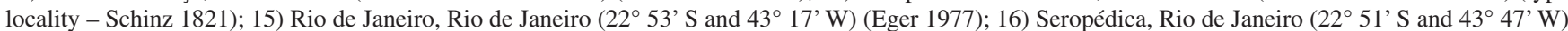

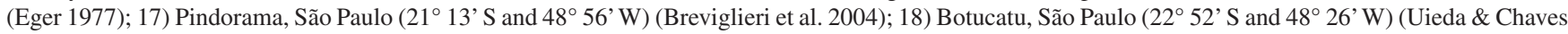

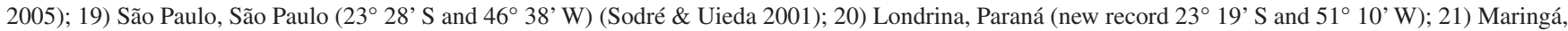

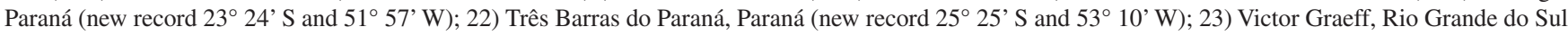
$\left(28^{\circ} 33^{\prime} \mathrm{S}\right.$ and $\left.52^{\circ} 44^{\prime} \mathrm{W}\right)$ (Pacheco \& Freitas 2003).

Quaternary have also been found in the North East of Brazil, State of Bahia (Czaplewski \& Cartelle 1998).

According to Eger (1977), there is a E. perotis male preserved in alcohol at the Institut Royal des Sciences Naturelles de Belgique (IRSNB), attributed to a location in the State of Goiás named "Parano do Manhana" (sic). We have investigated the origin of this specimen together with the curator of the IRSNB (G. Lenglet in litt.), and have corrected its provenance to "Paranã do Manhana", a locality in the high Amazon River where the Hungarian naturalist Carl Lako worked and gathered naturalia starting in the 1920s, when he stayed in the state of Amazonas, Brazil (v. Keve \& Samuél 1969, Hershkovitz 1985, 1987, Gutsche et al. 2007). In the registers of the IRSNB (original 
label 1449) the specimen appears as caught in July 1930, bought to Mr. Flemming, and entered the museum in 1936 (G. Lenglet in litt.). Its occurrence in the northwestern region of Brazil is a second example of apparent sympatry of E. perotis and E. trumbulli, as already determined by collection records of both species in northern Bolivia (Eger, 2007).

Thus, we are reporting the first records of E. perotis for the State of Paraná, in Southern Brazil. The absence or very few records of this and other molossid bats in vast geographical areas of Brazil is probably due to the methods generally used in inventories and/or the lack of effort to capture them. In Brazil, the State Health Departments access a large number of bats annually in order to diagnose the rabies virus. This material, which has a singular scientific value, can be utilized through partnerships with researchers to increase the knowledge of species which are difficult to sample by traditional methods.

\section{Acknowledgements}

We are indebted to the Divisão de Vigilância em Zoonoses e Intoxicações (Secretaria de Estado da Saúde do Paraná) for access to study material and Marcelo Alejandro Villegas Vallejos for reviewing this paper. We also thank Enrico Bernard and Suely A. Marques-Aguiar, curator of the Mammals Division of the Museu Paraense Emílio Goeldi, for information on the species in the states of Amazonas and Pará, George Lenglet, curator of the Institut Royal des Sciences Naturelles de Belgique, for information sent concerning the species label of "Paranã do Manhana", and especially to Fernando Costa Straube for his valuable literature review on the life of Carl Lako in Brazil and Judith Eger for additional suggestions that improved the manuscript.

\section{References}

BAKER, R.J., McDONOUGH, M.M., SWIER, V.J., LARSEN, P.A., CARRERA, J.P. \& AMMERMAN, L.K. 2009. New species of bonneted bat, genus Eumops (Chiroptera: Molossidae) from the lowlands of western Ecuador and Peru. Acta Chirop. 11(1):1-13.

BARQUEZ, R.M., MARES, M.A. \& BRAUN, J.K. 1999. The Bats of Argentina. The Museum of Texas Tech University, Lubbock-Texas. Special Publications 42:1-273.

BEST, T.L., KISER, W.M. \& FREEMAN, P.W. 1996. Eumops perotis. Mamm. species. 534:1-8.

BREVIGLIERI, C.P.B., CHAVES, J.R.D. \& TADDEI, F.G. 2004. Levantamento de Quirópteros da Mata Ciliar do Córrego dos Tenetes, Pindorama, SP. In Livro de Resumos do XXIII Congresso Brasileiro de Zoologia, Cuiabá, Mato Grosso, p. 239.

CZAPLEWSKI, N.J. \& CARTELLE, C. 1998. Pleistocene bats from cave deposits in Bahia, Brazil. J. mammal. 79:784-803.

DE LA PUENTE, O.J. 1951. Estúdio monografico de los quirópteros de Lima y arredores. Universidade Nacional Mayor de San Marcos. Publicaciones Del Museu de Historia Natural "Javier Prado", Serie A 7: 1-45.

EGER, J.L. 1977. Systematics of the Genus Eumops (Chiroptera: Molossidae). Life Sci. Contrib. 110:1-69.

EGER, J.L. 2007. Family Molossidae. In Mammals of South America: Marsupials, Xenarthrans, Shrews, and Bats (A.L. Gardner, eds). The University of Chicago Press, Chicago, p. 400-439.

ESCARLATE-TAVARES, F. \& PESSÔA, L.M. 2005. Bats (Chiroptera, Mammalia) in Barn Owl (Tyto Alba) pellets in Northern Pantanal, Mato Grosso, Brazil. Mastozool. Neotrop. 12(1):61-67.

FALCÃO, F.C., REBÊLO, V.F. \& TALAMONI, S.A. 2003. Structure of a bat assemblage (Mammalia, Chiroptera) in Serra do Caraça Reserve, South-east Brazil. Rev. Bras. Zool. 20(2):347-350.

FREEMAN, P.W. 1981. A multivariate study of the family Molossidae (Mammalia: Molossidae): morphology, ecology, evolution. Fieldiana, Zool. 7:1-173.
GREGORIN, R. \& TADDEI, V.A. 2002. Chave artificial para a identificação de Molossídeos brasileiros (Mammalia, Chiroptera). Mastozool. Neotrop. 9(1):13-32.

GUTSCHE, A., KWET, A., KUCHARZEWSKI, C., LINGNAU, R. \& GÜNTHER, R. 2007. Wilhelm Ehrhardt and an evaluation of his amphibians and reptiles held in the Herpetological Collection of the Museum für Naturkunde, Berlin. Mitt. Mus. Nat.kd. Berl., Zool. Reihe 83(1):80-93.

HERSHKOVITZ, P. 1985. Titis, new world monkeys of the genus Callicebus (Cebidae, Platyrrhini): a preliminary taxonomic review. Fieldiana, Zool. New Series 55:109.

HERSHKOVITZ, P. 1987. The taxonomy of South American Sakis, Genus Pithecia (Cebidae, Platyrrhini): A preliminary report and critical review with the description of a new species and a new subspecies. Am. J. Primatol. 12:387-468.

KEVE, A. \& SAMUÉL N. 1969. Hungarian Ornithologists and Bird-collectors Abroad and Overseas. Opusc. Zool. Budapest 9(2):339-356.

KOOPMAN, K.F. 1982. Biogeography of the bats of South America. In Mammalian Biology in South American. The Pymatuning Symposia in Ecology (M.A. Mares \& H.H. Genoways,eds). Pymaturing Laboratory of Ecology, University of Pittsburgh, Pennsylvania, p. 1-539. Special Publication Series, 6.

MARINKELLE, C.J. 1968. Importancia de los murciélagos del tropico americano en la salud publica. In Medicina tropical (A. Anselmi, ed). Talleres Gráficos de Editorial Fournier, México, Distrito Federal, México, p. $142-168$.

McDONOUGH, M.M., AMMERMAN, L.K., TIMM, R.M., GENOWAYS, H.H., LARSEN, A.L. \& BAKER, R.J. 2008. Sperciation within Bonneted Bats (Genus Eumops): the complexity of morphological, mitochondrial, and nuclear data sets in systematics. J. mammal. 89(5):1306-1315.

MILLER, G.S. Jr. 1906. The families and genera of bats. Bulletin of the Unites States National Museum 57:1-65.

PACHECO, S.M. \& FREITAS, T.R.O. 2003. Quirópteros. In Livro Vermelho da Fauna Ameaçada de extinção no Rio Grande do Sul (Fontana, C.S., Bencke, G.A. \& Reis, R.E., orgs.). Porto Alegre: EDIPUCRS, 632p.

PICCININI, R.S. 1974. Lista provisória dos quirópteros da coleção do Museu Paraense Emílio Goeldi (Chiroptera). Bol. Mus. Para. Emilio Goeldi, Zool. 7:1-32.

SANBORN, C.C. 1932. The bats of the genus Eumops. J. mammal. 13:347-357.

SIMMONS, N.B. 2005. Order Chiroptera. In Mammals Species of the World: a taxonomic and geographic reference (D.E. Wilson \& D.M. Reeder, eds). Johns Hopkins University Press, Baltimore, 312-529.

SODRÉ, M.M. \& UIEDA, W. 2001. Ato dos morcegos adentrar edificações no Município de São Paulo, SP. In Caderno de Resumos do I Congresso Brasileiro de Mastozoologia, 2001, Porto Alegre, RS, 2001, p. 65-65.

SODRÉ, M.M., DA ROSA, A.R., GREGORIN, R. and GUIMARÃES, M.M. 2008. Range extension of Thomas' Mastiff bat Eumops maurus (Chiroptera: Molossidae) in northern, central and southeastern Brazil. Rev. Bras. Zool. 25(2):379-382.

STUTZ, W.H., ALBUQUERQUE, M.C., UIEDA, W., MACEDO, E.M. \& FRANÇA, C.B. 2004. Updated list of Uberlândia bats. Chiropt. neotrop. 10(1-2):188-190.

TAVARES, V.C., GREGORIN, R. \& PERACCHI, A.L. In press. A diversidade de morcegos no Brasil. In Morcegos no Brasil: biologia, sistemática, ecologia e conservação (S.M. Pacheco, R.V. Marques \& C.E.F. Esberard, eds.). Armazém Digital, Porto Alegre, p. 25-60.

TIMM, R.M. \& GENOWAYS, H.H. 2004. The Florida bonneted bat, Eumops floridanus (Chiroptera: Molossidae): Distribution, morphometrics, systematics, and ecology. J. mammal. 85(5):852-865.

UIEDA, W. \& CHAVES, M.E. 2005. Bats from Botucatu Region, State of São Paulo, Southeastern Brazil. Chiropt. neotrop. 11(1-2):224-226. 